\title{
Edukacyjna inżynieria memetyczna W kierunku szkoły demokratycznej
}

\section{Educational memetic engineering Towards democratic school}

\section{Dominika Hofman-Kozłowska*}

\begin{abstract}
Abstrakt
Celem podjętym w artykule jest przeanalizowanie modelu organizacyjnego szkoły demokratycznej. Przykładem, który posłuży do zobrazowania tego modelu, będzie najstarsza szkoła demokratyczna na świecie — szkoła Summerhill z Wielkiej Brytanii, działająca od prawie stu lat. Szczególną uwagę zwrócimy na wizję i wartości, które stanęły u jej podstaw, oraz wynikające $\mathrm{z}$ nich podejście do dziecka. W artykule przedstawione zostaną także konkretne rozwiązania dotyczące organizacji nauki i czasu wolnego oraz prac samorządu. Przyporządkujemy też model szkół demokratycznych do odpowiadającego im poziomu rozwoju organizacji. Posłuży do tego koncepcja dynamiki spiralnej Clare'a W. Gravesa (Spiral Dynamics Model). Koncepcja ta nie była wykorzystywana na gruncie polskim do analizy modeli organizacyjnych szkoły.
\end{abstract}

\begin{abstract}
The object of this article is to analyze the democratic school's organizational model. The example used to visualize this model is the oldest democratic school in the world - 100 years old Summerhill School in Great Britain. We will put the emphasis on the vision and values on which the school was built and how it influenced the approach to children. This article will also describe solutions for teaching organization, free time and self-government. It will also assign democratic school model to corresponding level of organization development. It will be based on the idea of Spiral Dynamics Model by Clare W. Graves. This idea has not been used in Poland to analyze organizational model of school.
\end{abstract}

Key words: School's organizational model, democratic schools, Summerhill, self-government in school, Spiral Dynamics Model, green organizations

* doktorant (hofman.dominika@gmail.com); ORCID: 0000-0001-6840-3269. 
Słowa kluczowe: modele organizacyjne szkół, szkoły demokratyczne, Summerhill, samorząd szkolny, koncepcja dynamiki spiralnej, zielone organizacje

\section{Wprowadzenie}

Jak pisze Frederic Laloux — badacz organizacji: „[...] w przeciągu wieków typy organizacji [...] wiązały się zawsze $\mathrm{z}$ dominującym w danym okresie światopoglądem"'. Gdy zmieniał się sposób myślenia, zmieniały się organizacyjne formy zarządzania. W niniejszym artykule zastanowimy się, jak zmienia się dziś myślenie o kluczowej dla społeczeństwa i państwa organizacji, jaką stanowi szkoła. Celem podjętym w artykule jest analiza, mało jeszcze znanego w Polsce, szczególnie w obszarze edukacji publicznej, modelu szkoły demokratycznej tzw. zielonej organizacji. Przykładem, który posłuży nam do zobrazowania tego modelu, będzie najstarsza szkoła demokratyczna na świecie — szkoła Summerhill z Wielkiej Brytanii. W artykule przedstawione zostaną konkretne rozwiązania organizacyjne, wynikające $\mathrm{z}$ jej prawie stuletniego doświadczenia, oraz wartości, które stoją u podstaw jej funkcjonowania. Zastanowimy się też, z czego model demokratyczny wyrasta i pokrótce w jakich kierunkach może się rozwijać. Posłuży nam do tego, dobrze ugruntowana w doświadczeniu, koncepcja Dynamiki Spiralnej Clare’a W. Gravesa (Spiral Dynamics Model). We wstępie do książki Spiral Dynamics Mastering Values, Leadership, and Change ${ }^{2}$ autorzy podkreślają, że koncepcja ta daje strukturę, która służy lepszemu zrozumieniu dynamicznych procesów między innymi w obszarze edukacji. W polskiej literaturze koncepcja ta przywoływana była do analizy procesów edukacyjnych przez Piotra Błajeta ${ }^{3}$ i Marzannę Bogumiłę Kielar ${ }^{4}$. Nie była jednak wykorzystywana na gruncie polskim do analizy modeli organizacyjnych szkoły.

${ }^{1}$ F. Laloux: Pracować inaczej. [Przeł. M. Konieczniak]. Warszawa 2015, s. 22.

2 D.E. Beck, Ch.C. Cowan: Spiral Dynamics. Mastering Values, Leadership, and Change. Hoboken, N.J., 1996.

3 Por. P. BŁajet: Od edukacji sportowej do olimpijskiej. Studium antropologiczne. Kraków 2012.

${ }^{4}$ M.B. KIELAR: Integralna wizja Kena Wilbera i jej zastosowanie w edukacji. Warszawa 2012. 


\section{Świadomość a organizacyjne formy zarządzania}

Aby zrealizować cel przedstawiony we wstępie, konieczne jest dość szczegółowe przedstawienie założeń stojących u podstaw koncepcji Dynamiki Spiralnej. Nawiązuje ona do idei memów (Idea of Memes) Richarda Dawkinsa przedstawionej w książce Samolubny gen ${ }^{5}$. Zaproponował on określenie „mem” dla podstawowej jednostki informacji kulturowej zdolnej do powielania i ewolucji. Termin ten dobrze wyjaśnia i popularyzuje biolog, dydaktyk i memetyk Marek Kaczmarzyk: ,[...] mem — umowna jednostka informacji, której dystrybucja odbywa się drogą przekazu kulturowego, między innymi w procesach nauczania i wychowania. [...] Memem może być symbol, plotka, teoria naukowa lub przepis kulinarny. Wszystko, co może być przekazywane w zrozumiały dla innych sposób i ma znaczenie dla ich działania w systemie społecznym"6. Memy są poniekąd „genami kultury"7.

Koncepcja Dynamiki Spiralnej (por. rys. 1) powstała w wyniku badań, prowadzonych od lat sześćdziesiątych do osiemdziesiątych XX wieku pod przewodnictwem profesora psychologii Clare'a W. Gravesa ${ }^{8}$. Badaniami objęto ponad 50 tys. osób na całym świecie i w różnych kręgach kulturowych. Koncepcja została rozwinięta przez Dona Becka i Christophera Cowana, którzy wykorzystali ją w procesie zmian politycznych w Republice Południowej Afryki (m.in. w reformie gospodarki i oświaty oraz rozwiązywaniu konfliktów etnicznych) 9 .

Graves na podstawie wspomnianych badań wyodrębnił osiem poziomów świadomości, które, używając terminologii memetycznej, są odpowiednikami mempleksów, czyli w uproszczeniu zespołów memów związanych z jakimś obszarem rzeczywistości ${ }^{10}$ (por. schem. 1). Beck i Cowan nazwali owe poziomy vMemes (value-attracting meta-memes). Każdy z nich jest wynikiem interakcji między warunkami życia (problemami i wyzwaniami egzystencji) a zdolnościami adaptacyjnymi. Jak pisze Kielar: „Pod wymienionymi nazwami należy rozumieć ogólne [...] wzory przenikające konstrukty myślowe i schematy decyzyjne uczestniczące w interpretacji rzeczywistości i odzwierciedlające się w dowolnym działaniu"11.

${ }^{5}$ R. Dawkins: Samolubny gen. Przeł. M. Skoneczny. Warszawa 2006.

${ }^{6}$ M. KaczmarzyK: Zielony mem. Mikołów 2012, s. 92.

7 Ibidem.

${ }^{8}$ C.W. Graves: Levels of Existence. An Open System Theory of Values. "Journal of Humanistic Psychology" 1970, Vol. 10, No 131.

9 Por. D.E. Beck, G. Linscott: The Crucible: Forging South Africa's Future. Honeydew 1991.

${ }^{10}$ M. Kaczmarzyk: Zielony mem..., s. 92.

${ }^{11}$ M.B. KielaR: Jak rozwijaja się ludzkie systemy wartości — https://www.edurada.pl/ artykuly/jak-rozwijaja-sie-ludzkie-systemy-wartosci/ (dostęp: 15.10.2018). 


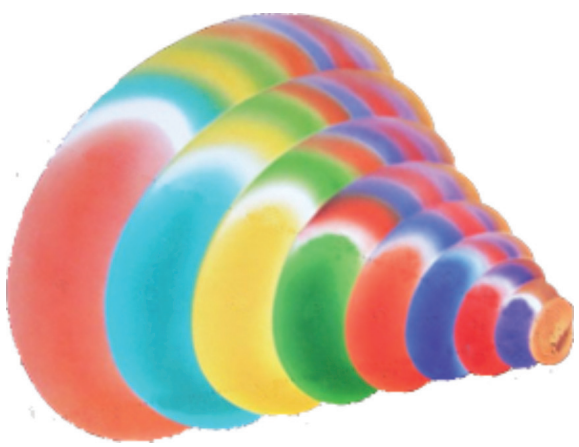

Rys. 1. Dynamika spiralna.

Źródło: Opracowanie własne na podstawie D.E. BeCK, Ch.C. Cowan: Spiral Dynamics. Mastering Values, Leadership, and Change. Hoboken, N.J., 1996

Manifestacją tych poziomów — vMemów — są między innymi przekonania, konkretne wartości, opinie, cele, pomysły, określone wybory i zachowania, a co szczególnie ważne w tym artykule — różne rozwiązania organizacyjne i formy zarządzania występujące w szkołach.

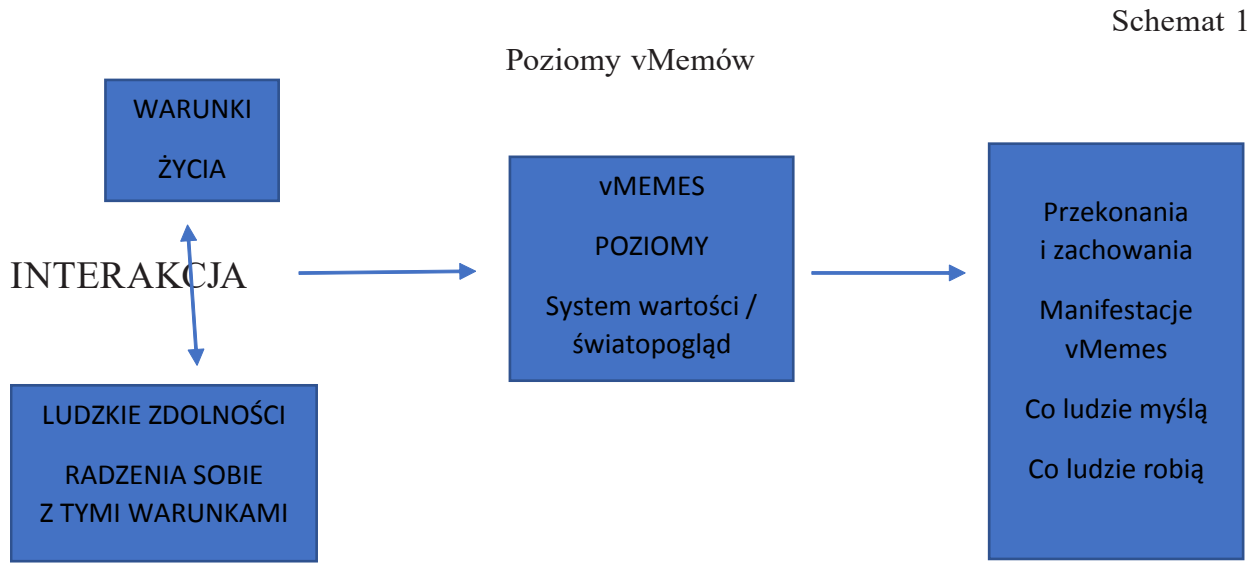

Źródło: Opracowanie własne na podstawie D.E. BeCK, Сн.C. Cowan: Spiral Dynamics. Mastering Values, Leadership, and Change. Hoboken, N.J., 1996

Tabela 1 przedstawia osiem zidentyfikowanych w badaniach poziomów. Sześć pierwszych (od beżowego do zielonego) stanowi pierwszą warstwę spirali i nazywanych jest poziomami egzystencji, przetrwania, ponieważ skupia się na podstawowych potrzebach ludzkich. Potem następuje rewolucyjna zmiana, pojawiają się dalsze poziomy (źółty i turkusowy) zwane poziomami istnienia, ponieważ dotyczą jakości egzystencji ${ }^{12}$.

12 Por. K. GrzesiK, M. KwieciŃSKa: Wykorzystanie wybranych aspektów teorii integralnej w kreowaniu nowego podejścia do przywództwa. "Managment Forum" 2016, Vol. 4, No 4, s. 20; P. BŁAJEt: Od edukacji sportowej do olimpijskiej... 
Charakterystyka podstawowych vMemów w koncepcji Dynamiki Spiralnej

\begin{tabular}{|c|c|c|}
\hline vMem & Podstawowy kod & Cechy charakterystyczne \\
\hline Beżowy & przeżycie & $\begin{array}{l}\text { koncentracja na działaniach, które umożliwiają prze- } \\
\text { trwanie; błyskawiczne reakcje typowe dla mózgu } \\
\text { gadziego - walka/ucieczka }\end{array}$ \\
\hline $\begin{array}{l}\text { Fioletowy / } \\
\text { purpurowy }\end{array}$ & $\begin{array}{l}\text { więzi, } \\
\text { przynależność }\end{array}$ & $\begin{array}{l}\text { okazywanie lojalności wobec starszyzny, plemienia } \\
\text { i jego zwyczajów; kultywowanie świętych miejsc, } \\
\text { przedmiotów, rytuałów; tworzenie więzi po to, by } \\
\text { przetrwać i odnaleźć bezpieczeństwo; życie odbierane } \\
\text { jako magiczne }\end{array}$ \\
\hline Czerwony & $\begin{array}{l}\text { egocentryzm, } \\
\text { siła i moc }\end{array}$ & $\begin{array}{l}\text { przeświadczenie, że najważniejsza jest własna osoba; } \\
\text { walka o utrzymanie kontroli za wszelką cenę }\end{array}$ \\
\hline Niebieski & $\begin{array}{l}\text { celowość, } \\
\text { porządek }\end{array}$ & $\begin{array}{l}\text { poświęcenie samego siebie dla ,jedynej słusznej } \\
\text { drogi”; porządek, stabilność, dyscyplina, zasady — to } \\
\text { ważne wartości; bycie częścią hierarchicznej struktury }\end{array}$ \\
\hline Pomarańczowy & $\begin{array}{l}\text { przedsiębiorczość } \\
\text { sukces }\end{array}$ & $\begin{array}{l}\text { dążenie do autonomii i ciągłych zmian; poszukiwanie } \\
\text { „dobrego życia” i dostatku; rozwój poprzez wyszu- } \\
\text { kiwanie najlepszych rozwiązań; podnoszenie jakości } \\
\text { życia społeczeństwa poprzez technologię; nastawienie } \\
\text { na wygraną i poczucie radości ze współzawodnictwa }\end{array}$ \\
\hline $\begin{array}{l}\text { Zielony } \\
\text { [podkr. - } \\
\text { D.H.-K.] }\end{array}$ & $\begin{array}{l}\text { humanizm, } \\
\text { społeczność }\end{array}$ & $\begin{array}{l}\text { eksploracja wnętrza u siebie i innych; pro- } \\
\text { mowanie poczucia wspólnoty i jedności; dziele- } \\
\text { nie zasobów wspólnoty pomiędzy wszystkich; } \\
\text { próba jednomyślnego lub kompromisowego podej- } \\
\text { mowania decyzji }\end{array}$ \\
\hline Żółty & $\begin{array}{l}\text { integralność, } \\
\text { synergia }\end{array}$ & $\begin{array}{l}\text { świadomość ekologiczna - akceptacja nieuchron- } \\
\text { ności rytmów natury; dążenie do syntezy różnych } \\
\text { światopoglądów; działanie we własnym interesie bez } \\
\text { krzywdzenia innych; doświadczanie pełni życia na } \\
\text { Ziemi tu i teraz; dążenie do elastyczności i otwartych } \\
\text { systemów }\end{array}$ \\
\hline Turkusowy & holizm & $\begin{array}{l}\text { działanie na rzecz integracji, harmonizowanie, silne } \\
\text { poczucie wspólnoty; przywiązywanie dużej wagi do } \\
\text { dobra wszystkich żywych istot; poszerzanie świado- } \\
\text { mości; traktowanie siebie jako części większej całości; } \\
\text { dążenie do minimalistycznego stylu życia }\end{array}$ \\
\hline
\end{tabular}

Źródło: Opracowanie własne na podstawie D.E. Beck, CH.C. Cowan: Spiral Dynamics..., 1996.

Zgodnie z modelem dynamiki spiralnej rozwój przebiega etapami, na zasadzie ,przekraczania i włączania”. Każdy vMem reprezentuje kolejny etap rozwoju i oznacza wejście na wyższy poziom psychologiczno-kulturowy, który jest bardziej złożony w stosunku do poprzedniego. Na przykład dotarcie do poziomu czerwonego oznacza „włączenie” także wcześniejszych poziomów — beżowego i purpurowego. Im bardziej złożone okoliczności, tym bardziej złożone systemy wartości są wymagane. Każdy następny poziom spirali prowadzi w przypadku 
zarówno jednostek, jak i grup, do większej ekspresji w myśleniu, szczególnie $\mathrm{w}$ procesie konceptualizacji oraz $\mathrm{w}$ zdolnościach do wcielania $\mathrm{w}$ życie większej liczby sposobów poznania i działania ${ }^{13}$. W ujęciu Gravesa, rozwój człowieka, społeczności czy organizacji jest „emergentnym, oscylującym, spiralnym procesem, który cechuje się stopniowym podporządkowywaniem się starszych struktur, niższego rzędu, strukturom nowszym, węższego rzędu, w miarę jak zmieniają się egzystencjalne uwarunkowania rozwoju"14. Co ważne, człowiek wykorzystuje jeden lub więcej vMemów, które najczęściej są zgodne z dominującym vMemem kultury, w jakiej żyje. Zarówno w społecznościach, organizacjach, jak i w życiu jednostek może występować jednocześnie kilka aktywnych vMemów, w zależności od konkretnych warunków życia. Każdy z vMemów ma też swoje i pozytywne, i negatywne, ograniczające, strony.

Koncepcja ta nie stanowi wyczerpującego opisu rozwoju systemów wartości jednostki czy organizacji (taki opis jest niemożliwy), ale w tym przypadku dostarcza cennych wskazówek do przeprowadzenia analizy różnych modeli organizacyjnych szkół, ze szczególnym uwzględnieniem modelu szkoły demokratycznej.

\section{Ewolucja modeli organizacyjnych}

Liczna grupa naukowców ${ }^{15}$, w tym przywołany Graves, poddała analizie drogę ludzkiego rozwoju — rozwoju świadomości, systemów wartości. Od początku historii ludzkości doświadczyliśmy kilku etapów. Laloux, badacz organizacji, zwraca jeszcze uwagę na to, że za każdym razem, gdy ludzkość wchodziła na nowy etap, wymyślała inny sposób współpracy, czyli nowy model organizacyjny. Organizacje, jakie znamy dzisiaj, są wyrazem naszego obecnego światopoglądu, naszego poziomu rozwoju.

W tabeli 2 przedstawiona została krótka charakterystyka siedmiu różnych typów organizacji przypisanych poszczególnym poziomom — vMemom z modelu dynamiki spiralnej ${ }^{16}$. Z perspektywy dalszych rozważań zawartych w niniejszym artykule, vMemy niebieski i zielony są kluczowe.

${ }^{13}$ K. GrZesiK, M. KwiecińSKA: Wykorzystanie wybranych aspektów teorii integralnej..., s. 19.

${ }^{14}$ Clare W. Graves Homepage - http://www.clarewgraves.com/home.html (dostęp: 15.10.2018)

${ }_{15}$ Przykładem niech będą: koncepcja o ewolucji potrzeb (Maslow), światopoglądów (Gebser), zdolności poznawczych (Piaget), rozwoju moralności (Kohlberg), tożsamości (Loevinger), duchowości (Fowler), przywództwa (Cook-Greuter, Kegan, Torbet)

${ }^{16}$ Szerszy opis znajduje się w książce F. Laloux: Pracować inaczej... 
Zmieniające się modele organizacyjne

\begin{tabular}{|c|c|c|}
\hline vMem & Przykład organizacji & Krótka charakterystyka \\
\hline Beżowy & $\begin{array}{l}\text { grupy } \\
\text { skladające się } \\
\text { z kilkudziesięciu } \\
\text { osób oparte na } \\
\text { więziach } \\
\text { rodzinnych } \\
\end{array}$ & $\begin{array}{l}\text { poczucie tożsamości nie jest oddzielone od innych } \\
\text { członków grupy i środowiska; zbieractwo jest pod- } \\
\text { stawą egzystencji; podział pracy nie jest wymagany } \\
\text { (wyjątek mogą stanowić kobiety rodzące i wychowu- } \\
\text { jące dzieci), więc nie ma jeszcze modelu organiza- } \\
\text { cyjnego }\end{array}$ \\
\hline Purpurowy & plemię & $\begin{array}{l}\text { świat wydaje się magiczny; w celu jego okiełznania } \\
\text { plemiona szukają pocieszania w rytualnych zachowa- } \\
\text { niach, podążają za starszyzną }\end{array}$ \\
\hline Czerwony & $\begin{array}{l}\text { protoimperium, } \\
\text { gangi uliczne, } \\
\text { mafie }\end{array}$ & $\begin{array}{l}\text { ego jest już ukształtowane; umożliwia to powstanie } \\
\text { struktury i podział ról — stałe sprawowanie silnej } \\
\text { władzy przez wodza w celu utrzymania innych } \\
\text { w ryzach; spoiwem organizacji jest lęk; wysoce reak- } \\
\text { tywny sposób działania; koncentracja na krótkoter- } \\
\text { minowych celach }\end{array}$ \\
\hline Niebieski & $\begin{array}{l}\text { Kościól, wojsko, } \\
\text { większość agencji } \\
\text { rządowych, } \\
\text { systemy szkół } \\
\text { publicznych }\end{array}$ & $\begin{array}{l}\text { wysoce sformalizowane role w hierarchicznej pira- } \\
\text { midzie; niebieskiej organizacji ważna jest dbałość } \\
\text { o porządek, hierarchia, stabilność i przewidywalność } \\
\text { oraz biurokratyczny, powtarzalny proces realizowany } \\
\text { na podstawie odgórnych dyrektyw }\end{array}$ \\
\hline Pomarańczowy & \begin{tabular}{|l|} 
korporacje, \\
szkoły społeczne
\end{tabular} & $\begin{array}{l}\text { jest w niej przestrzeń na kreatywność i innowację; } \\
\text { zarządzanie następuje przez cele (kontrola nad tym, } \\
\text { jakie to cele, wolność w sposobie ich realizacji); } \\
\text { ważne są wyniki, osiągnięcia, zysk i w konsekwencji } \\
\text { pokonanie konkurencji }\end{array}$ \\
\hline Zielony & $\begin{array}{l}\text { organizacje, } \\
\text { napędzane } \\
\text { kulturą firmy, } \\
\text { organizacje } \\
\text { pozarządowe, } \\
\text { szkoły } \\
\text { demokratyczne } \\
\end{array}$ & $\begin{array}{l}\text { zielona organizacja opiera się na kulturze pracy opar- } \\
\text { tej na określonych wartościach; szuka sprawiedli- } \\
\text { wości, równości, harmonii, wspólnoty, współpracy } \\
\text { i zgody; wartości te i dobre relacje są często ważniej- } \\
\text { sze od wyników; organizacje te koncentrują się na } \\
\text { upełnomocnieniu pracownika/ ucznia, przekazaniu } \\
\text { mu możliwie jak największej odpowiedzialności }\end{array}$ \\
\hline \begin{tabular}{|l|} 
Żółty \\
(turkusowy)
\end{tabular} & $\begin{array}{l}\text { przykład: szkoła } \\
\text { publiczna w Ber- } \\
\text { linie ESBZ, pod } \\
\text { kierownictwem } \\
\text { Margret Rasfeld*, } \\
\text { polskie przykłady: } \\
\text { producent opako- } \\
\text { wań Masterpress, } \\
\text { sieć przedszkoli } \\
\text { LeanCE** }\end{array}$ & $\begin{array}{l}\text { metaforą, która najlepiej opisuje żółte/turkusowe } \\
\text { organizacje jest metafora żywego organizmu lub } \\
\text { żywego systemu; Laloux wymienia trzy przełomy, } \\
\text { które dzieją się na tym etapie: samozarządzanie - } \\
\text { samoorganizujące się zespoły, system oparty na rela- } \\
\text { cjach, bez potrzeby hierarchii czy modelu konsensu; } \\
\text { integralność - uwzględnienie wszystkich aspektów } \\
\text { ludzkiego rozwoju; cel ewolucyjny - poszukiwanie } \\
\text { sensu w podejmowanych działaniach, misja organiza- } \\
\text { cji nabiera prawdziwego znaczenia }\end{array}$ \\
\hline
\end{tabular}

* Przykłady organizacji: F. Laloux: Pracować inaczej..., s. 73-76.

** T. StaŚKiewicz: Wszyscy będziemy turkusowi — https://innpoland.pl/127905,wszyscy-bedziemy -turkusowi-nowy-paradygmat-zarzadzania-w-firmie-przyszlosci (dostęp: 15.10.2018).

Źródło: Opracowanie własne na podstawie F. Laloux: Pracować inaczej. [Przeł. M. Konieczniak]. Warszawa 2015. 


\section{Zielona organizacja}

Na etapie pomarańczowym podział na dobre i złe, jakimu hołduje vMem niebieski, został zastąpiony myśleniem w kategoriach: działa — nie działa, sukces - porażka. Na etapie zielonym zaś, zwanym przez Laloux pluralistycznym, uznaje się, że takie dychotomiczne myślenie jest zbytnim uproszczeniem. Ważne staje się uwzględnienie wielu perspektyw i wprowadzanie demokratycznych procesów.

Tak jak w poprzednich przypadkach, zielony vMem wypracowuje nowy sposób myślenia, który przekłada się na funkcjonowanie organizacji. Z zielonego vMemu wyłania się przekonanie, że w świetle trwających nierówności życie powinno być czymś więcej niż tylko podążaniem ścieżką kariery i sukcesu. Dla ludzi i organizacji działających z tej perspektywy relacje i dbałość o otoczenie są ważniejsze od wyników. Tomasz Skalski pisze: „Zielony światopogląd jest więc kolektywistyczny, wrażliwy, ekologiczny, równościowy; świadomość jest szeroka i systemowa. Cena, którą płacisz, wstępując na ten poziom - to przede wszystkim utrata hierarchii, rozmycie wszelkich podziałów, eliminacja umiejętności ważenia i oceniania różnych spraw: powszechne zrównanie wszystkich poglądów"17. W kontekście działania organizacji, pisze Laloux, zielony vMem zakłada, że „wszystkie punkty widzenia powinny być traktowane na równi, lecz utyka w impasie, gdy inni wykorzystują jego tolerancję, by forsować nietolerancyjne pomysły [...]. Zieleń jest potężnym paradygmatem ze względu na obalanie starych struktur, jednak często jest mniej efektywna w formułowaniu praktycznych alternatyw"18.

Laloux zwraca uwagę na trzy przełomy, które zaistniały w wybranych organizacjach dzięki zielonemu vMemowi, a które wzajemnie się przenikają i uzupełniają. Pierwszy z nich dotyczy upełnomocnienia. Mimo iż zielone organizacje zachowują hierarchiczną strukturę, to większość decyzji w nich podejmowanych zostaje przekazana w dół. Dzięki temu pracownicy pierwszego kontaktu w firmach, uczniowie w szkołach, mogą podejmować decyzje w szerszym niż dotychczas zakresie, bez akceptacji zarządzających czy nauczycieli. Możliwość realnej partycypacji w procesach decyzyjnych wzmacnia ich podmiotowość i współodpowiedzialność za organizację. Wprowadzenie decentralizacji do organizacji przywykłych do praktyk charakterystycznych dla etapu niebieskiego lub pomarańczowego nie jest łatwym dokonaniem. Drugi przełom związany jest z kulturą organizacyjną opartą na wartości i inspirującym celu. Organizacje czują się coraz częściej zobligowane, aby podążać za chwilową modą, i określają zbiór wartości, wywieszają go na ścianie czy stronie

\footnotetext{
17 Ibidem, s. 77.

18 Ibidem, s. 44.
} 
internetowej, a w toku codziennej pracy zapominają o nim. Zielone organizacje powstają wokół wspólnych wartości albo wypracowują je zespołowo w stale trwającym procesie. Przełom trzeci wiąże się z uwzględnieniem perspektywy wszystkich grup interesu. W przypadku szkoły chodzi o dyrekcję, nauczycieli oraz innych pracowników, rodziców, a przede wszystkim uczniów. Społeczna odpowiedzialność zielonych organizacji nie jest tylko utartym frazesem, ale często rdzeniem ich misji i działalności. W przypadku szkół łączy się ona poniekąd z takim wspieraniem młodych ludzi, aby w przyszłości byli oni w stanie aktywnie, na zasadach demokratycznych i pokojowych, partycypować we współtworzeniu różnych wspólnot.

\section{Summerhill - demokratyczna i samorządna szkoła}

Czy za prekursora zielonego modelu szkoły możemy uznać Alexandra S. Neilla, który w 1921 roku założył Summerhill? Z pewnością jego twórczość i działalność rozpoczyna się od zakwestionowania wartości i rozwiązań, na których opierają się szkoły tradycyjne, wywodzące się z niebieskiego vMemu, i szkoły progresywne, wywodzące się z pomarańczowego vMemu. Czy jednak te trzy przełomy, o których wspomina Laloux: 1) upełnomocnienie, 2) kultura organizacyjna oparta na wartościach i inspirującym celu oraz 3) uwzględnienie perspektywy wszystkich grup interesu — zaistniały w ramach tej pierwszej szkoły demokratycznej na świecie? Analizując Summerhill jako „zieloną organizację", warto zwrócić uwagę na wizję i wartości, które legły u jej podstaw, a także na wynikające $\mathrm{z}$ nich konkretne rozwiązania $\mathrm{w}$ obszarze organizacji nauki, czasu wolnego, samorządu.

\section{Podstawowa wizja Neilla}

W celu zrozumienia podstawowych założeń, wokół których zbudowana została koncepcja Neilla, przydatne może okazać się podejście Thomasa Sowella, przedstawione w książce Konflikt wizji - ideologiczne poczatki walk politycznych ${ }^{19}$. Wykorzystanie modelu stworzonego przez Sowella pozwoli nam ustrukturyzować często dość chaotyczny i pobieżny wywód Neilla i wyłonić podstawowe przesłanki, leżące u podstaw jego twórczości i działalności. Sowell ukazuje powtarzalność pewnych sporów jako zderzenie dwóch wizji metapoli-

19 T. Sowell: The Conflict of Visions. Ideological Origins of Political Struggles. New York 1987. 
tycznych rozumianych jako typy idealne w sensie weberowskim ${ }^{20}$ : ograniczonej (realistów-pragmatyków) i nieograniczonej (idealistów-moralistów). Pojmowanie możliwości i ograniczeń jednostki w ramach każdej z tych grup różni się tak bardzo, że przekłada się na zróżnicowane koncepcje funkcjonowania państwa, gospodarki czy wreszcie szkoły.

Z wizji ograniczonej wyłania się założenie, mówiące raczej o niezmienności natury ludzkiej, natury, która jest niedoskonała pod względem zarówno intelektualnym, jak i moralnym. Aby okiełznać egocentryczną naturę ludzką, można powołać instytucje, które będą podejmować pozytywne działania opierające się na stworzonym systemie zachęt, ale też nakładać ograniczenia, które utrudnią wyrządzanie szkody innym. Ludzie mogą być samolubni, egoistyczni, stąd też tylko wyznaczenie pewnych ram sprawi, że będą mogli funkcjonować jako społeczeństwo.

Sowell, tworząc swój model, nie brał pod uwagę działaczy i myślicieli edukacyjnych, jednak gdyby to zrobił, to umieściłby Neilla wśród przedstawicieli nieograniczonej wizji ${ }^{21}$. Istotę nieograniczonej wizji, szczególnie w kontekście edukacyjnym, dobrze oddaje przekonanie Neilla, że natura ludzka ma skłonność do bycia dobrą, a nieświadome procesy nie są w żaden sposób niemoralne. „Tylko wypaczona siła dąży do zła. Ludzie są dobrzy, chcą być dobrzy, chcą kochać i być kochani. Nienawiść i bunt są tylko miłością i siłą, które udaremniono" ${ }^{22}$.

Osoby, którym bliżej do wizji nieograniczonej, kładą nacisk raczej na dyspozycję wewnętrzną człowieka niż na stosowanie zewnętrznych ograniczeń lub zachęt. Podążają za naturalnymi etapami rozwoju człowieka. Według nich siły społeczne stanowią często przyczynę antyspołecznych zachowań (nie tak, jak w opozycyjnej wizji, gdzie antyspołeczne zachowania są hamowane przez siły społeczne). Neill i jego mentor Lane pisząc o tym, że są „po stronie dziecka”, mieli na myśli to, że surowe nauczanie moralne czasów, w których żyli, było jedną z praktyk, które wyrażały dezaprobatę wobec dziecka, wobec jego instynktów i zainteresowań. Widzieli siebie stojących za dziećmi, unikających pokusy ingerowania $w$ ich interesy i dających im wolność bycia sobą. Przedstawiciele nieograniczonej wizji człowieka podzielali wniosek, że wartości moralne rozwijają się, gdy dzieci nie są na określonej, szczegółowo wytyczonej ścieżce ich kształtowania. $Z$ tego też powodu Neill utrzymywał, żeby nie ingerować, a zaufać procesom samoregulacji. „Samoregulacja zakłada wiarę w dobroć natury ludzkiej, przekonanie, że nie ma i nigdy nie było, grzechu pierworodnego"23 — pisze Neill, podkreślając tym samym swoje przywiązanie do nieograniczonej wizji człowieka.

${ }^{20}$ Zob. M. Gierycz, P. Mazurkiewicz: Dwie wizje czlowieka - dwie wizje Europy. „Chrześcijaństwo - Świat - Polityka” 2014/2015, nr 17/18, s. 17.

${ }^{21}$ Por. R. Bailey: A.S. Neill. London-New York 2013, s. 126-129.

22 A.S. Neill: Summerhill. Szkoła wolnych ludzi. Przeł. B. Bialecka. Warszawa 2014, s. 440.

${ }^{23}$ Ibidem..., s. 153. 
Jakie wartości i jakie cele są ważne dla Neilla i wynikają z nieograniczonej wizji? „Uważam, że celem życia jest szczęście, a to oznacza sprecyzowanie zainteresowań" ${ }^{24}$ - pisze. Zainteresowania zaś wiążą się według niego z każdą, naturalną aktywnością dziecka: ,[...] prawdziwe zainteresowanie jest siłą życiową całej osobowości, a jako takie jest całkowicie spontaniczne. [...] Nie można wymusić zainteresowania"25. Neill na wiele różnych sposobów podkreślał, że „złem życia jest wszystko to, co ogranicza je lub niszczy”26. Próbował znosić ograniczenia, ponieważ twierdził, że tylko w warunkach możliwie największej wolności można osiągnąć szczęście. Wśród przeszkód, stojących dzieciom na drodze ku szczęściu, wymieniał: szkolnictwo, które według niego represjonuje (tradycyjne - niebieski vMem) lub manipuluje (progresywne — pomarańczowy vMem), wymuszanie posłuszeństwa poprzez dyscyplinę, kary, nagrody, niemożność wyrażenia siebie przy rodzicach i nauczycielach, ograniczenia dotyczące seksualności dzieci, tradycję i religię. Pisał: „Jak można obdarzać szczęściem? Moja własna odpowiedź brzmi: znieść autorytet. Pozwól dziecku być sobą. Nie pomiataj nim. Nie pouczaj. Nie praw kazań. Nie umoralniaj go. Nie zmuszaj do robienia czegokolwiek”27. Jak podkreśla Wincenty Okoń, Neillowi „przyświecała Roussowska zasada: umieć nic nie robić z wychowaniem" ${ }^{28}$. Tyle tylko, że w wypadku Neilla „nie była już ideą filozoficzną, lecz żywą tkanką codziennej pracy z dziećmi" 29 .

Zarówno podstawowa wizja pojmowania świata i dziecka, jak i wynikające z niej wartości wpłynęły na kształt organizacji, którą Neill powołał do życia „zielonej organizacji”.

\section{Organizacja procesu nauki}

Nauka w Summerhill zorganizowana jest zgodnie z planem dnia, ustalonym na Zebraniu Ogólnym całej społeczności. Aktualny plan z 2018 roku $^{30}$ jest

${ }^{24}$ A.S. NeILL: Summerhill..., s. 42.

${ }^{25}$ Ibidem, s. 231.

${ }^{26}$ Ibidem, s. 80.

27 A. Neill: Nowa Summerhill. Przeł. M. Duch. Poznań 1994, s. 197.

28 W. OKoń: Dziesięć szkót alternatywnych. Warszawa 1999, s. 144.

${ }^{29}$ Ibidem.

${ }^{30}$ Informacje zdobyte podczas wizyty studyjnej w Summerhill w roku 2014. Od 9:00 każdego dnia tygodnia w Summerhill rozpoczynają się lekcje (stan na 2018 r.). Dzieci poniżej 12. roku życia mają przypisanych własnych nauczycieli i wielozadaniową, wyodrębnioną przestrzeń (rodzaj domku). W klasie I (5-9 lat) nauczyciel nawet co tydzień ustala rozkład zajęć, odpowiadający aktualnym potrzebom dzieci. Klasa II (10-12) na początku semestru ma wypisane przedmioty i projekty do wyboru. Przestrzenie dla klasy I i II są zaprojektowane tak, aby osoby, które nie chcą uczestniczyć w zajęciach, mogły przebywać w tym samym domku i angażować się w wybraną przez siebie aktywność, niezwiązaną z harmonogramem. 
w dużej mierze podobny do tego, który funkcjonował za czasów Neilla. Zakres oferowanych przedmiotów i dzisiaj, i w przeszłości, kształtuje się, poza paroma wyjątkami, dość standardowo ${ }^{31}$. Uczniowie od początku istnienia Summerhill mogli brać udział w dodatkowych projektach, które wynikały z potrzeb uczniów, ale i możliwości finansowych szkoły ${ }^{32}$. W wolnym czasie dzieci mogą dziś korzystać z odkrytego basenu latem, pracowni stolarskiej, plastycznej, komputerowej, fotograficznej, teatralnej, muzycznej. Mogą uprawiać różne sporty, pisać do szkolnej gazety, jeździć po rampie na deskorolce, wspinać się po drzewach, bawić się w lesie i podążać za swą wyobraźnią ${ }^{33}$.

Nie ma wątpliwości, że Neill krytycznie odnosił się do koncentracji jedynie na „,zdolnościach akademickich”. Jako że współczesne systemy edukacyjne również w dużej mierze kładą na nie nacisk, to jego rozważania, mimo iż powstały na przełomie XIX i XX wieku, są dziś zadziwiająco aktualne. Nacisk na academic ability, który był i jest charakterystyczny dla większości systemów edukacyjnych na świecie, oznacza według znanego badacza edukacji Kena Robinsona przede wszystkim redukcję inteligencji do logicznego rozumowania. Myślenie w kategoriach academic ability wiąże się z tym, co Horst Siebert określa jako dydaktykę pouczania ${ }^{34}$ — „odartą z wszelkiego przeżywania" ${ }^{35}$. Transportowanie wiedzy od nauczyciela do uczniów, z pominięciem uświadamiania sobie faktu, że proces uczenia się jest zależny od „biograficznie uwarunkowanych struktur sensorycznych, poznawczych i emocjonalnych"36, sprawia, że uczniowie nie są zdolni do uczenia się, a jedynie do bycia pouczanymi. Dlatego Siebert proponuje dydaktykę umożliwiania, która — jak pisze Andrzej Murzyn — „wykracza poza technologię nauczania" ${ }^{37}$. Dydaktyka umożliwiania wiąże się dla Robinsona $z$ uwzględnieniem i wzmocnieniem emocjonalnej strony uczenia się. Aspekt ten dużo wcześniej pojawił się w twórczości Neilla i stanowił podstawę jego dalszych rozważań dotyczących edukacji i procesu uczenia się. Opowiedze-

Uczniowie starsi mogą brać udział w lekcjach ze standardowych przedmiotów. Lekcje te odbywają się w przygotowanych do tego przestrzeniach — osobnych, drewnianych domkach. Metody, cele, programy lekcji ustala nauczyciel w porozumieniu z uczniami.

${ }^{31}$ Zakres przedmiotów na rok 2018 kształtuje się następująco: science - biologia, fizyka, chemia; matematyka, język angielski i literatura, niemiecki, hiszpański, japoński, chiński, stolarka, sztuka, dramat, historia, geografia, technologia muzyczna, technologia informacyjna, wokal.

32 Przykładowe projekty funkcjonujące w Summerhill w 2018 r.: prace ogrodowe, gra w dyplomację, psychologia dla dzieci, mozaiki, fotografia i photoshop, popołudniowe spacery, tworzenie wideo, lekcje „magiczne”, szachy.

${ }_{33}$ Por. www.summerhillschool.co.uk (dostęp: 15.12.2018)

${ }^{34}$ H. Siebiert: Metody pracy kształceniowej. Podręcznik nauczania aktywizujacego. Przeł. A. Murzyn. Kraków 2005, s. 123, za: A. Murzyn: Wokół Kena Robinsona kreatywnego myślenia o edukacji. Kraków 2013, s. 20.

35 Ibidem.

${ }^{36}$ Ibidem.

${ }^{37}$ Ibidem. 
nie się po emocjonalnej stronie tego procesu oznaczało dla Neilla opowiedzenie się za budowaniem głębszych niż dotychczas relacji między nauczycielami a uczniami.

Neill krytycznie odnosił się do pamięciowego uczenia się pod przymusem. Mało tego, rozwój intelektualny uczniów nie stanowił dla niego priorytetu. On wręcz nie zachęcał dzieci do rozwoju poprzez czytanie i uczenie się z książek. Twierdził, że „książki w szkole są najmniej ważne” ${ }^{38}$. W książce Dreadful School wspomina: „Rodzice bardzo powoli uświadamiają sobie, jak mało ważna jest edukacyjna funkcja szkoły"39.

Neill, pracując długie lata w szkołach systemowych, zdawał sobie sprawę z tego, jak wygląda hierarchia ważności przedmiotów. Na szczycie plasowały się (a może i nadal plasują) matematyka i pozostałe przedmioty ścisłe oraz języki obce. W środku hierarchii znajdują się przedmioty humanistyczne. Na samym dole hierarchii mieszczą się przedmioty artystyczne. Neill prawie sto lat temu postanowił tę tendencję odwrócić. To, co zrobił, uchodziłoby za działanie rewolucyjne także i dziś: „Tym, czego potrzebuje każde dziecko, jest: pisanie, czytanie i arytmetyka, resztę powinny stanowić narzędzia, glina, sport, teatr,

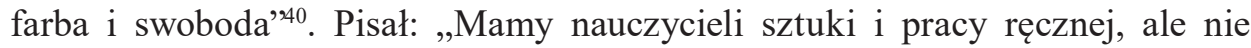
stać mnie już na nauczycieli tańca lub muzyki — dla mnie dużo ważniejszych niż nauczyciele matematyki lub historii”’11. $Z$ oferowanego planu zajęć podstawowych i dodatkowych wynika, że ważna była dla niego praca twórcza: „Być może grupa naszych dwunastolatków nie mogłaby konkurować z klasą równolatków pod względem kaligrafii, ortografii czy ułamków, lecz w egzaminach wymagających oryginalności nasze dzieci pobiłyby resztę na głowę"ł2. Uważał, że duże znaczenie dla rozwoju młodych ludzi ma między innymi teatr. Po dziś dzień działania teatralne są w centrum aktywności szkolnej.

Neill kwestionował jeszcze jedną cechę systemów edukacji, wskazaną przez Robinsona - presję oceniania. Od dzieci oczekuje się, aby ich umiejętności były na coraz wyższym poziomie, przy czym poziom ten ustalany jest na podstawie wyników z testów czy klasówek. Za tego typu działaniami ukryte jest przekonanie, że uczeń powinien wiedzieć coraz więcej, lecz w coraz bardziej ograniczonej dziedzinie; powinien być specjalistą. Neill pisał o szkołach systemowych przełomu XIX i XX wieku jako o „kombinatach dających masową produkcję" ${ }^{\text {"43. }}$; produkcję człowieka jednowymiarowego, oddzielonego od swego złożonego potencjału. Ubolewał, że w kombinatach tych ,wszelkie nagradzanie, stopnie i egzaminy sprawiają, że właściwy rozwój osobowości staje się

\footnotetext{
38 A.S. NeILL: Summerhill..., s. 44.

39 A.S. Neill: The Dreadful School. London 1936, s. 29.

40 A.S. NeILl: Summerhill..., s. 44.

${ }^{41}$ A.S. NeILl: The Dreadful School..., s. 154.

${ }^{42}$ A.S. NeILL: Summerhill..., s. 17.

${ }^{43}$ Ibidem, s. 47.
} 
drugoplanowy" ${ }^{\prime 4}$. Wiedział na podstawie swojego doświadczenia, że życie nie jest ustrukturyzowane ani linearne, a dynamiczne, zróżnicowane i zależne od zmiennych okoliczności. Wartości i dobre relacje były dla niego ważniejsze od wyników i ocen, co między innymi świadczy o tym, że Summerhill może być uznane za organizację wyrastającą z zielonego vMemu.

Sposobem na zgłębienie pełnego zakresu swoich zdolności i zainteresowań

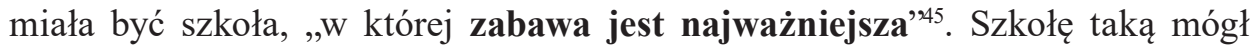
stworzyć tylko człowiek, który sam czerpał przyjemność z zabawy i fantazjowania. Neill niewątpliwie był takim człowiekiem, dlatego też był w stanie zrozumieć naturalną potrzebę zabawy u dzieci. Neill wielokrotnie podkreślał, że „uczenie powinno następować po zabawie. I nie należy go umyślnie przyprawiać zabawą po to, by było strawne"46. Zabawa to najważniejsza $\mathrm{z}$ form dziecięcej aktywności, rozwijająca wyobraźnię, wolność wewnętrzną, a w związku z tym i podmiotowość człowieka. Wpływa też ona na rozwój więzi społecznych, integrację środowiska, a to elementy kluczowe dla funkcjonowania szkoły opartej na idei samorządności. Integralną częścią zabawy, do której Neill przykładał dużą wagę, był ruch. Nie wyobrażał sobie jednak, aby w jego wolnej szkole uczniowie chcieli uczęszczać na zorganizowane lekcje wychowania fizycznego czy brać udział w zmaganiach na boisku sportowym. Uważał, że ruch jest częścią życia i po prostu ma się wydarzać przy okazji codziennych czynności, przy okazji zabawy ${ }^{47}$.

Rozwiązaniem organizacyjnym, które według Neilla wspiera proces upełnomocnienia dzieci, jest zasada dobrowolnego udziału w lekcjach. To jedna z ważniejszych zasad obowiązujących w Summerhill, ściśle przestrzegana przez całą społeczność i po dziś dzień budząca spore kontrowersje. Uczniowie mogą całe dnie (a nawet lata, jak pokazuje doświadczenie) spędzać na kanapie, na drzewie lub gdziekolwiek chcą (ważne, aby byli na terenie szkoły). O tym, niezwykle rewolucyjnym, pomyśle pisze była summerhilianka Dane Goodsman: „Lekcje nie były uważane za centrum życia szkolnego; stały się jednym z wielu sposobów dostępnych w procesie »samokształcenia«. Miały dużą wartość, ponieważ były do wyboru, a dla smmerhilian to właśnie wybór był edukacyjny. Poprzez wybór dzieci mają możliwość poznania obowiązków wynikających z podejmowania własnych decyzji. [...] Edukacja w Summerhill była postrzegana jako proces emancypacyjny, pozwalający jednostkom być niezależnymi istotami”"48. Goodsman nie ma wątpliwości, że dobrowolność uczęszczania na lekcje wpływa na kształtowanie poczucia odpowiedzialności za własne życie.

44 Ibidem, s. 44.

45 Ibidem, s. 94.

46 Ibidem, s. 45.

47 Ibidem, s. $110-112$.

48 D. Goodsman: Summerhill: Theory and Practice. Unpublished Doctoral Thesis. Norwich 1992, s. 225; za: R. BAIley: A.S. Neill..., s. 159. 
Popularne jest przekonanie, że Neill i nauczyciele, których zatrudniał, stosowali nowoczesne, nieautorytarne metody, które odpowiadały alternatywnemu charakterowi szkoły. Tak jednak nie było. Lekcje przyjmowały raczej formę tradycyjną, często wykładową, były „prowadzone przez nauczyciela”. Goodsman podkreśla, że praktykowano raczej konserwatywną dydaktykę. Wynikała ona jej zdaniem $\mathrm{z}$ tego, że w szkole nie było problemów z dyscypliną, na lekcje chodziły tylko te osoby, które chciały tam być, które miały motywację. Jeśli ktoś przeszkadzał innym, sprawa mogła być omówiona i rozwiązana na zebraniu ogólnym. Nauczyciele nie musieli więc zmieniać i dostosowywać praktyk dydaktycznych, aby utrzymać zainteresowanie lub porządek. Goodsman wspomina także, że te tradycyjne praktyki opierały się na „kredzie i rozmowie”49. Cechą Summerhill jest przecież mocno równościowa relacja między nauczycielami a uczniami. Może i nauczyciele nie stosują żadnych specjalnych, wyszukanych metod i narzędzi, ale rozmową i szacunkiem - uwzględniając potrzeby ucznia - uczą jakby przy okazji. Metody są sprawą wtórną. W tym kontekście nawet tradycyjna metoda wykładowa, która nie cieszy się dziś dobrą sławą, nie była postrzegana w Summerhill negatywnie.

Od nauczycieli przedmiotowych, pracujących w Summerhill, oczekuje się, że będą mogli uczyć do poziomu $\mathrm{GCSE}^{50}$, gdyby jacyś uczniowie chcieli zdawać egzamin i zdobyć świadectwa szkoły średniej, które są przepustką do świata akademickiego, choć kompetencje związane z przygotowaniem do egzaminów nie były jednak dla Neilla najważniejsze. „Mój personel i ja — pisał Neill — serdecznie nie lubimy wszelakich egzaminów. Dla nas to zmora. Nie możemy jednak odmówić uczenia dzieci wymaganych przedmiotów. [...] Nie oznacza to wcale, że wiele dzieci chce zdawać te egzaminy, zdają je tylko ci, którzy idą na uniwersytet" ${ }^{51}$. Wiedział on, że podporządkowanie działań nauczycieli z góry określonym celom edukacyjnym i szczegółowym wytycznym, pozbawia ich pedagogicznej twórczości i w konsekwencji ogranicza ich autonomię. Rekrutacja do szkoły podlegała specyficznym kryteriom: „Jej dyrektor starał się przyjmować pedagogów, którzy nie byli moralistami, mieli poczucie humoru i byli osobami twórczymi" ${ }^{2}$. Wiedział, że tylko nauczyciele mający jakieś zainteresowania, zrozumieją potrzebę odkrywania ich przez uczniów. Wiedział, że tylko nauczyciele mający silne poczucie sprawstwa, zaakceptują niezależne działania uczniów. Według Neilla, codzienna praca nauczycieli powinna właści-

${ }^{49}$ Por. ibidem.

${ }^{50}$ GCSE (The General Certificate of Secondary Education) - egzamin zdawany powszechnie w trakcie piątego roku nauki w szkole średniej (ang. Secondary Education) przez uczniów w wieku 16 lat w Anglii, Walii i Irlandii Północnej. Jest to warunek konieczny do kontynuowania nauki w systemie A-levels lub matury międzynarodowej.

51 A.S. Neill: Summerhill..., s. 19.

${ }^{52}$ R. BrZEZińSKA, A. BRZEZIŃSKi: Idee angielskiej wolnej szkoty Summerhill w polskich egzemplifikacjach. Włocławek 2012, s. 39-40. 
wie ograniczać się do zapewnienia sprzyjającego środowiska i tworzenia atmosfery, w której może nastąpić naturalny rozwój.

\section{Demokratyczna rodzina}

Uczniowie Summerhill mają wolność robienia czegokolwiek (przez lata mogą bawić się i chodzić po drzewach). Przyzwolenie na decyzyjność dziecka w tak szerokich granicach jest edukacyjną rzadkością w skali światowej. Jedynie dwie zasady ograniczają te granice: zasada nieszkodzenia innym i podstawowe zasady bezpieczeństwa zapewniane przez dorosłych. Pojawia się tu jednak pytanie: Jak, odrzucając sposoby autorytarne, jeśli nie za pomocą jakiejś formy organizacji społecznej, dbać między innymi o zasadę nieszkodzenia innym?

Neill uzupełnia swoją definicję wolności o dodatkowy aspekt. Twierdzi, że stajemy się wolni, przyjmując postawę aktywną, będąc podmiotem kształtującym rzeczywistość, a nie przedmiotem działania. „Był przekonany o tym, że nie można mówić o wolności, jeśli uczniom nie daje się swobody rządzenia życiem szkolnym" 53 - podkreślał Okoń. Tak pojmowana wolność, którą cechuje doświadczenie, przejawia się w Summerhill głównie w postaci funkcjonowania samorządu. Samorząd był i jest najważniejszym doświadczeniem dla uczniów; doświadczeniem, które daje ogromne poczucie sprawstwa i wspiera proces rozwoju zarówno osobistego, jak i społecznego. Stanowi rdzeń doświadczenia Summerhill. W wielu szkołach na świecie, także i dziś, samorząd jest tylko parawanem dla kierownictwa. Dla Neilla był autentycznym organem sprawowania władzy nad szkołą i internatem oraz ich działalnością. To, jaki wpływ miały dzieci na funkcjonowanie swojej szkoły na początku XX wieku, dzięki rozwojowi unikatowej koncepcji samorządności, która świadczy o demokratycznym charakterze szkoły, zasługuje na szczególną uwagę.

Samorząd działa w ramach czterech form organizacyjnych: komitetów, rzeczników, trybunału i - co najważniejsze - Ogólnego Spotkania Szkoły. Spotkania te (General School Meetings) odbywają się co tydzień. Są one przykładem realizacji jednej z zasad zielonych organizacji: uwzględniania perspektywy wszystkich grup interesu, gdyż uczestniczy w nich cała społeczność szkolna łącznie z personelem. Każdemu uczestnikowi spotkania, zarówno dyrektorowi, jak i 7-letniemu dziecku, przysługuje jeden głos, a zatem uczniowie mają zdecydowaną przewagę. Dzięki temu rozwiązaniu większość decyzji dotyczących funkcjonowania szkoły zostaje w praktyce przesunięta w dół. Obszary, które zarezerwowane są dla dyrekcji i nauczycieli, dotyczą: przyjmowania i zwalniania pracowników, organizacji zaopatrzenia, kontrolowania systemu pożarniczego, zakupu mebli czy doboru podręczników ${ }^{54}$.

53 W. OкоŃ: Dziesięć szkót..., s. 151.

${ }^{54}$ R. BrzezińsKa, A. Brzeziński: Idee angielskiej wolnej szkoły..., s. 36. 
Na Ogólnych Spotkaniach Szkoły ustanawia się i egzekwuje zasady zamieszczone w regulaminie. Mimo radykalnie wręcz wolnościowego charakteru szkoły obowiązuje w niej ok. 200 zasad wypracowanych przez całą społeczność. Zasady te jednak mogą podlegać ciągłym zmianom. Rzecznikami praw są uczniowie wybierani na okres 14 dni. Zajmują się rozstrzyganiem drobnych sporów, badaniem spraw i wsparciem osoby, która ma otrzymać karę. Poważniejszymi sprawami zajmuje się trybunał. Jest to rodzaj sądu, do którego wnosi się prywatne sprawy, jeśli ktoś ma poczucie, że został skrzywdzony. W trakcie Ogólnego Spotkania Szkoły wybierane są też osoby, które wejdą w skład różnych komitetów: sportowego, teatralnego, komitetów dyżurnych do spraw ciszy nocnej i komitetu „miejskiego”, który czuwa nad zachowaniem uczniów poza murami szkoły ${ }^{55}$.

Jakie atuty wynikają z działalności rozbudowanego samorządu, poza ochroną zasady nieszkodzenia innym? Przede wszystkim samorząd wnosił sobą wartość edukacyjną. Neill był przekonany, że doświadczanie rządzenia sobą i współrządzenia społecznością, której jest się częścią, stanowi najcenniejsze dobro w edukacji, a przede wszystkim w życiu: „Moim zdaniem jedno cotygodniowe Ogólne Spotkanie Szkoły jest więcej warte niż całotygodniowy zestaw przedmiotów szkolnych" "56. Samorząd oferuje dzieciom doświadczenie bycia aktywnym obywatelem, doświadczenie działania w strukturze demokratycznej, doświadczenie wpływu. Neill wiedział też, że decyzje wynikające z procesu demokratycznego, z pracy samorządu, z głosu większości spotkają się z przychylniejszym odbiorem uczniów niż te odgórne, wydane poza ich wpływem. Uczeń, który w ramach spotkania samorządu otrzymuje karę (np. jakieś zadanie do wykonania na rzecz wspólnoty), rzadko wnosi sprzeciw, gdyż sam współtworzy obowiązujące zasady i kreuje otaczającą go rzeczywistość. Dodatkowo, dzięki działalności samorządu, nauczyciele zostają zwolnieni z obowiązku dyscyplinowania niedopuszczalnych zachowań, co pozwala im nawiązywać bliższe relacje z uczniami. To spłaszczenie struktury jest także jedną z cech ,zielonych organizacji”.

Laloux do opisu ,zielonych organizacji” używa metafory rodziny. Które elementy mogą świadczyć o tym, że wspólnota Summerhill ma charakter rodzinny? Jedną z nich jest niewątpliwie wspólne mieszkanie na terenie szkoły zarówno uczniów, jak i dyrekcji oraz części nauczycieli. Uczniowie wracają do rodziców tylko podczas 1 i 2 trymestru na 4,5 tygodnia, a podczas 3 trymestru - na 9 tygodni wakacyjnej przerwy. Rodzice uczniów nie mają wpływu na kształt szkoły i jej funkcjonowanie, co jest wyraźnie podkreślone na stronie internetowej Summerhill ${ }^{57}$. W szkole zazwyczaj jest od 65 do 75 dzieci i około 16 pełnoetatowych pracowników. Jak czytamy na stronie: ,[...] to mała społeczność dzieci

${ }_{55}$ Badania własne, przeprowadzone w 2014 r. podczas wizyty w Summerhill.

56 A.S. NeILl: Summerhill..., s. 84.

57 Strona internetowa szkoły Summerhill — http://www.summerhillschool.co.uk/thevery-basics.php (dostęp: 12.01.2019) 
i dorosłych, którzy żyją razem" 58 . Neill twierdził, że w Summerhill nie ma szefa lub że jest nim społeczność szkolna. Jak pisze jednak Goodsman - absolwentka szkoły, za wszystkim stał jednak szef, założyciel i właściciel szkoły. Był on siłą przewodnią, niejako ojcem całej społeczności. Na podstawie jego koncepcji szkoła została zbudowana. Był przywódcą społeczności Summerhill i jako mający tę rolę musiał ustrukturyzować jej działanie, ustrukturyzować wolność w swoich kategoriach. Nie ma w tym nic dziwnego. Do tego przecież zachęcał też dzieci. Struktura, którą stworzył i która właściwie w niezmienionym kształcie funkcjonuje do dziś, pozwala dzieciom na rozwój zarówno indywidualny, jak i społeczny. Tak „dzieje się w najlepszych rodzinach” ${ }^{59}$, podkreśla wydawca książki Nowa Summerhill.

\section{Zakończenie}

W kontekście modelu dynamiki spiralnej padają pytania: Czy może być tak, że dominujący obecnie światopogląd i system wartości ograniczają nas w myśleniu na temat szkoły? Czy jesteśmy w stanie stworzyć bardziej złożony, humanistyczny i odpowiadający wymogom współczesności model organizacyjny sprzyjający uczeniu się, dzięki zmianie sposobu postrzegania, zmianie dominującego vMemu? Czy jesteśmy w stanie zainspirować się wartościami, podejściem do dziecka i wybranymi rozwiązaniami dotyczącymi stosunku do rozwoju i samorządu, zastosowanymi w Summerhill — „zielonej organizacji”?

Modele organizacyjne, w tym te, na których opiera się funkcjonowanie szkół, podlegają ciągłej zmianie. Odwołując się do modelu dynamiki spiralnej, kolejnym etapem rozwoju, który wymagałby odrębnych badań i opracowania, jest etap żółty - integralny (przez Laloux nazywany etapem turkusowym). Założyciele powstających dopiero na świecie ,żółtych organizacji” mówią o nich, używając następujących metafor: żywy organizm, żywy system. Podkreślają też, że w swych działaniach zmierzają ku większej różnorodności, złożoności, wyższej świadomości ${ }^{60}$. Skalski pisze, że to etap, który charakteryzuje się „myśleniem integrującym, systemowym, multiperspektywicznym" ${ }^{\circ 1}$.

Czy zatem musimy wybierać między modelem tradycyjnym (opierającym się na niebieskim vMemie), modelem progresywnym (opierającym się na vMemie pomarańczowym) a modelem demokratycznym (opierającym się na zielo-

\footnotetext{
58 Ibidem.

59 A.S. Neill: Nowa Summerhill..., s. 19.

${ }^{60}$ F. Laloux: Pracować inaczej...

61 T. SKalski: Projekt integralny. Życie i praca. Katowice 2014.
} 
nym vMemie)? Każdy z nich ma swoje słabe i mocne strony. Laloux zwraca uwagę na to, że jeśli nie będzie następowała stopniowa integracja kolejnych, dobrych rozwiązań wypracowanych $\mathrm{w}$ ramach określonych modeli, a szkoła ograniczy się do funkcjonowania tylko w ramach jednego z nich, może dojść do zaburzenia jej funkcjonowania. Zwłaszcza, gdy będzie wdrażała wybrany model w wersji radykalnej.

Jak pisze Kaczmarzyk: „Potrzebny nam pilnie jakiś rodzaj edukacyjnej inżynierii memetycznej, jednocześnie ostrożny i odważny kompromis pomiędzy działaniami wspierającymi memy zweryfikowane przez przeszłość i tymi, które umożliwiają bezpieczne (na ile to oczywiście możliwe) poszukiwanie nowych rozwiązań”62. A to, jak pisze Błajet, „oznaczałoby jednoczesne [podkr. D.H.-K.] respektowanie i uczenie respektowania praw biologicznych i społecznych oraz stwarzanie warunków dla dowolnej, eksploracyjnej aktywności ucznia" ${ }^{\prime 3}$.

\section{Bibliografia}

Bailey R.: A.S. Neill. London-New York 2013.

Beck Ch.C., Linscott G.: The Crucible: Forging South Africa's Future. Honeydew 1991.

Beck D.E., Cowan Ch.C.: Spiral Dynamics. Mastering Values, Leadership, and Change, Hoboken, N.J., 1996.

Beajet P.: (Nie)przypadkowa edukacja. Toruń 2016.

BŁAJET P.: Od edukacji sportowej do olimpijskiej. Studium antropologiczne. Kraków 2012.

BRZEZIŃsKa R., BRZEZIŃsKi A.: Idee angielskiej wolnej szkoły Summerhill w polskich egzemplifikacjach. Włocławek 2012.

Clare W. Graves Homepage - http://www.darewgraves.com/home.html (dostęp: 15.10.2018).

Dawkins R.: Samolubny gen. Przeł. M. Skoneczny. Warszawa 2006.

Dewey J.: Moje pedagogiczne credo. Przeł. J. Pieter. Lwów—Warszawa 1897.

Donohue W.A.: The New Freedom: Individualism and Collectivism in the Social Lives of Americans. New Brunswick, N.J., 1995.

Gierycz M., Mazurkiewicz P.: Dwie wizje czlowieka - dwie wizje Europy. „Chrześcijaństwo - Świat - Polityka” 2014/2015, nr 17/18.

Goodsman D.: Summerhill: Theory and Practice. Unpublished Doctoral Thesis. Norwich 1992.

${ }^{62}$ M. KaczmarzyK: Szkoła memów. W stronę dydaktyki ewolucyjnej. Gliwice 2018, s. 168.

${ }^{63}$ P. BŁajet: (Nie)przypadkowa edukacja. Toruń 2016, s. 11-12. 
Graves C.W.: Levels of Existence: an Open System Theory of Values. "Journal of Humanistic Psychology" 1970, Vol. 10, No 131.

GrZESIK K., KwIECIŃSKA M.: Wykorzystanie wybranych aspektów teorii integralnej w kreowaniu nowego podejścia do przywództwa. "Managment Forum” 2016, Vol 4, No 4.

KACZMARZYK M.: Szkoła memów. W stronę dydaktyki ewolucyjnej. Gliwice 2018.

KaCZMARZyK M.: Zielony mem. Mikołów 2012.

Kielar M.: Integralna wizja Kena Wilbera i jej zastosowanie w edukacji. Warszawa 2012.

KIElaR M.: Jak rozwijaja się ludzkie systemy wartości - https://www.edurada.pl/ artykuly/jak-rozwijaja-sie-ludzkie-systemy-wartosci/ (dostęp: 15.10.2018).

Kupisiewicz S.: Szkoła w XX wieku. Warszawa 2006.

Laloux F.: Pracować inaczej. [Przeł. M. Konieczniak]. Warszawa 2015.

Murzyn A.: Wokót Kena Robinsona kreatywnego myślenia o edukacji. Kraków 2013.

NeILl A.S.: Dreadful School. London 1936.

Neill A.S.: Nowa Summerhill. Przeł. M. Duch. Poznań 2000.

NeIll A.S.: Summerhill. Szkoła wolnych ludzi. Przeł. B. BiaŁeckA. Warszawa 2014.

OKоŃ W.: Dziesięć szkót alternatywnych. Warszawa 1999.

OкоŃ W.: Szkoły eksperymentalne w świecie: 1900—1960. Warszawa 1964.

Siebiert H.: Metody pracy kształceniowej. Podręcznik nauczania aktywizujacego. Przeł. A. Murzyn. Kraków 2005.

SkALSKi T.: Projekt integralny. Życie i praca. Katowice 2014.

Sowell T.: The Conflict of Visions. Ideological Origins of Political Struggles. New York 1987.

STAŚKIEWICZ T.: Wszyscy będziemy turkusowi — https://innpoland.pl/127905,wszy scy-bedziemy-turkusowi-nowy-paradygmat-zarzadzania-w-firmie-przyszlosci (dostęp: 15.10. 2018).

Strona internetowa szkoły Summerhill — http://www.summerhillschool.co.uk/thevery-basics.php (dostęp: 8.01.2019).

Dominika Hofman-Kozłowska, mgr, absolwentka studiów politologicznych na Uniwersytecie Śląskim w Katowicach. W obszarze naukowym podejmuje refleksję nad przyszłością i rozwojem szkoły. Jej zainteresowania badawcze koncentrują się wokół zagadnień z zakresu filozofii edukacji. Pracuje w Uniwersytecie Otwartym Uniwersytetu Śląskiego. Jest założycielką Uniwersytetu Śląskiego Maturzystów, którego prace koordynuje, oraz inicjatorką Otwartych Spotkań Dydaktycznych dla kadry uniwersyteckiej. Prowadzi szkolenia dla nauczycieli i edukatorów. Współpracuje ściśle z podmiotami takimi jak: Stowarzyszenie Miasta w Internecie oraz Collegium Wratislaviense, z którymi realizuje ogólno- 
polskie projekty, mające na celu zmianę podejścia do edukacji: Laboratorium Dydaktyki Cyfrowej, badanie kompetencji nauczycieli, rodziców i uczniów w zakresie radzenia sobie z zagrożeniami niesionymi przez technologie cyfrowe, badanie najnowszych metod z zakresu dydaktyki cyfrowej, Szkoła Tutorów, Innowacje w Edukacji. 